\title{
Acceptance of E-learning among university students in UAE: A practical study
}

\author{
Ahmad Qasim Mohammad AlHamad \\ Department of Management Information Systems, Abu Dhabi University, Al Ain, United Arab Emirates
}

\begin{tabular}{l} 
Article Info \\
\hline Article history: \\
Received Oct 11, 2019 \\
Revised Feb 2, 2020 \\
Accepted Feb 10, 2020 \\
\hline
\end{tabular}

\section{Keywords:}

Accessibility

E-learning systems

Enjoyment

Perceived ease of use

Subjective norm

Technology acceptance model

(TAM)

United Arab Emirates (UAE)

\begin{abstract}
The objective of the study is to find out the factors which affect the acceptance of E-learning among students and how the students' purpose of using E-learning is determined by these factors. The research was based on the Technology Acceptance Model (TAM). The researcher developed a questionnaire to gather data from a sample of 366 university students who actively used the E-learning system. According to the results of the study, subjective norms, perceived usefulness, perceived ease of use, enjoyment, and accessibility" are the vital predicators behind the intention of students for using E-learning systems. This indicates that extended TAM is applicable in the UAE. The results show that policymakers and education developers should take E-learning system seriously since it can be opted not just as a technological solution but also as a learning platform for students belonging to a distant area. The results present practical implications for education developers, policymakers and practitioners in devising useful plans to implement E-learning systems.
\end{abstract}

Copyright () 2020 Institute of Advanced Engineering and Science. All rights reserved.

\section{Corresponding Author:}

Ahmad Qasim Mohammad AlHamad,

Department of Management Information Systems,

Abu Dhabi University,

Sheikh Khalifa Bin Zayed Street, Al Ain - Abu Dhabi, United Arab Emirates.

Email: aqd14@yahoo.com

\section{INTRODUCTION}

As the Information technology continues to evolve at a very fast pace [1], World Wide Web, also called as the Web, has emerged as an influential source through which learning and teaching have become possible at a distance [2]. Through the Internet, users can get a lot of information and can get better chances to interact and cooperate with others. By relying on Internet, students can get access to several learning tools for devising new techniques and means for the implementation of the gathered knowledge or creating new ones [3]. Different terms like E-learning, online learning, and web-based learning are used to explain the teaching and learning experiences gained via the Internet and Web technology [4, 5]. E-learning refers to a virtual class through which different kinds of information can be achieved through the internet where, unlike an actual classroom environment, the teachers or students are not present [6]. Students can rely on Internet as a source of information through which they can learn whenever and wherever they want [7]. The course materials available on the Internet can be accessed at any time which means that students can study the same material repeatedly [5]. The flexibility and ease that E-learning offers are very fascinating for numerous students involving adults as well as professionals who might not have been able to get advanced degrees if the only option they had was the conventional studying technique. Several top organizations are now implementing E-learning into their present business operations [5]. Furthermore, many high education institutions and corporate training are adopting E-learning for sorting out different learning and performance related issues [5,8]. E-learning is among the most important modern advancements that occurred in the IS industry which has placed a new challenge for schools as well as the industry. It is important to study this topic as a number of schools are educating their students through E-learning 
courses $[9,10]$. Clearly, E-learning plays a vital part in a world where achieving the up-to-date information and expertise are important for benefitting from the present knowledge-based economy.

Organizations and educational institutions are keen to incorporate E-learning technology into their current practices as a source of learning so that target people and/or employees can be educated using the most updated information. As E-learning is becoming more common in the educational institutions, there is a need to study student acceptance of such technology because it is a critical factor in becoming successful in its application [11-13]. Significance of user acceptance behavior can be understood through different techniques. During the early stages, the end-users like students utilize the technology regularly for the purpose of studying. Any such decision which through which their learning behavior is influenced should be taken as their readiness to embrace the change. On the basis of this concept, the empirical evidence has demonstrated that technology acceptance which included end-users were more effective as compared to the technology acceptance where no end-users were involved [14]. To find out the causes of information technology acceptance, researchers have created numerous models and tested them. The Technology Acceptance Model (TAM [15], the theory of reasoned action (TRA) [16] are among the common theories. Though, the technology acceptance model (TAM) has achieved great scientific support via justifications, implementations, and repetitions. As compared to the other models, the TAM is considered as more predictive, robust and grasping [17]. In addition to this, on the basis of technology adoption literature, TAM is perceived as an important model in IS domain. The study intends to determine the causes of student's acceptance of learning in higher education setting through the integration of certain E-learning external factor external factor (Enjoyment, Accessibility, Subjective norm) which affect the Perceived Usefulness, Perceived Ease of Use, and to examine the ways in which these factors can form students' intention to employ E-learning. This involves direct authoritative inferences in backing the classy E-learning programs and encouraging the effective E-learning courses. The research has been structured in the following manner.

The subsequent part summarizes the literature review of the researches done on the area of E-learning system acceptance. Literature review and hypothesis included in the research have been explained in section two. Section three gives a detailed explanation of data analysis and findings. Results and discussions are offered in section four whereas the conclusion is explained in the last section along with major findings of the study.

\section{LITERATURE REVIEW AND HYPOTHESIS}

\subsection{External variables \\ 2.1.1. Enjoyment}

Enjoyment (ENJ) is defined as "the activity of using a specific system is perceived to be enjoyable in its own right, aside from any performance consequences resulting from system use" [18]. Enjoyment in the studies of technology acceptance has been fascinating various researchers since it is assumed that these intrinsic variables may have a positive effect on the users' views [19]. The enjoyment experienced while using a new system can minimize the perception of effort being made by the user [20]. Therefore, an important factor which describes the E-learning adoption or acceptance is perceived enjoyment. The previous research showed that perceived ease of use [21-28] and perceived usefulness [23, 27-29] of E-learning systems are significantly affected by the perceived enjoyment. When a student finds out that using E-learning systems is enjoyable, there is a higher possibility that usefulness and ease of use of such systems will positively impact that student [5]. Two hypotheses can be generated from the aforementioned arguments. H1a: Enjoyment has a significant influence on the perceived ease of use (PEOU).

H1b: Enjoyment has a significant influence on perceived usefulness (PU).

\subsubsection{Accessibility (ACC)}

Accessibility (ACC) refers to "the degree of ease of how a user can access and use the information and extracted from the system" [30]. According to [31], system accessibility refers to the degree of ease with which the students can access and use the E-learning system. It was stated that the more an E-learning system is easily accessible to the students, the higher the chances of students to consider the system as easy to use [32]. System accessibility, as per [33], directly signifies the website's perceived ease of use. Studies conducted by [26, 34-37] revealed that perceived ease of use of E-learning system is greatly affected by the system accessibility. The findings of the past researches show that an E-learning system's perceived ease of use [38] and perceived usefulness [39] are significantly affected by the perceived accessibility. When students can easily access the E-learning systems, there is a greater possibility that they will positively affect the usefulness and ease of use of such system [34, 35, 37, 40]. Therefore, the following assumptions are made:

H2a: Accessibility has a significant influence on the perceived ease of use (PEOU).

$\mathrm{H} 2 \mathrm{~b}$ : Accessibility has a significant influence on perceived usefulness (PU). 


\subsubsection{Subjective norm (SUB)}

Subjective norm and social influence is the idea that significant people believe that the system should either be used or not [41]. The subjective norm refers to "the person's perception that most people who are important to him or her think he or she should or should not perform the behavior in question" [42]. Under some circumstances, rather than concentrating on their personal emotions and beliefs, people may adopt a system just to adapt to the needs of others [43]. Many researchers have been conducted on how E-learning adoption or acceptance is affected by subjective norms. A research conducted by [22] showed that perceived ease of use $[9,22,23,25,36,37,44-46]$ and perceived usefulness of E-learning system [23, 37, 45-48] are considerably affected by subjective norms. Hence, the subsequent hypothesis has been developed:

H3a: Subjective norm has a significant influence on the perceived ease of use (PEOU).

$\mathrm{H} 3 \mathrm{~b}$ : Subjective norm has a significant influence on perceived usefulness (PU).

\subsection{The technology acceptance model and user beliefs}

The perceived usefulness and perceived ease of use aid the acceptance of new technology. TAM and other relevant studies show that these factors considerably affect the behavior intention to use. The views of a user concerning the ease of comprehending a system significantly aids in recognizing the effectiveness and the degree to which the user shows adoption to new technology $[49,50]$. A previous study demonstrated that perceived usefulness is considerably affected by the perceived ease of use (PEOU) [29, 40, 45, 46, 51-55]. There are many studies that show a direct as well as an indirect positive relationship between the behavioral intention to use E-learning system (IU) and perceived ease of use (PEOU) [29, 40, 46, 52, 54, 56-59]. It was stated by [51] that the intention to directly or indirectly approve of and adapt to an E-learning system will be affected by perceived usefulness (PU). The past studies show that there exists a positive connection between the perceived usefulness (PU) and intention to use the learning system (IU) [23, 54, 56, 60-66]. While keeping in view the literature, the research states the following hypotheses, along with showing a significant positive relationship between IU, PU, and PEOU.

H4: Perceived ease of use (PEOU) has a significant influence on the perceived usefulness (PU).

H5: Perceived usefulness (PU) has a significant influence on the intention to use the E-Learning system (IU). H6: Perceived ease of use (PEOU) has a significant influence on the intention to use the E-Learning system (IU).

The research model is based on these hypotheses as demonstrated in Figure 1. The theoretical model is first given the form of a structural equation model and then it is assessed by using scientific methods.

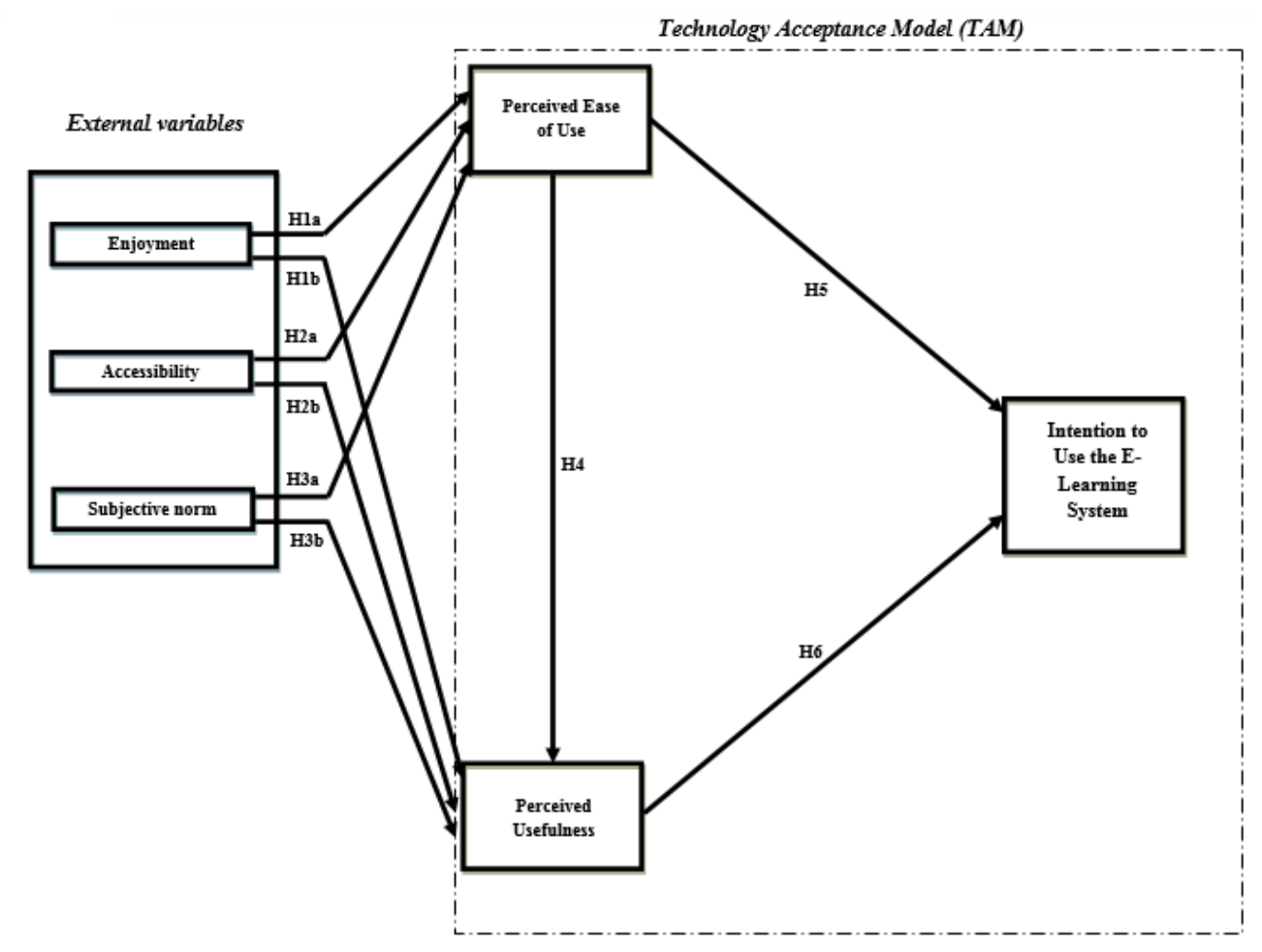

Figure 1.The study model 


\section{RESEARCH METHODOLOFY}

\subsection{Sample and data collection}

The data was gathered from two renowned educational institutions in the United Arab Emirates (UAE) who had been using E-learning systems. The online survey involved 400 respondents. Two web-based E-learning systems created by two E-learning platform/system providers were being used in these universities. These E-learning platforms were created and organized about 4 years before and were already being used by the students regularly. The study was carried out through Smart PLS Version T3.2.7 i.e. Structural equation modeling or SEM. SEM was used to assess this measurement model and final path model was managed in the later stages. A detailed image of the collected data has been shown in Table 1 . Thirty-four incomplete responses questionnaires had to be discarded from the gathered responses. After that, 366 questionnaires were available that were completed by the respondents which indicate a response rate of $91.5 \%$. A total of 366 responses which involved only valid responses were considered and transformed into a sample size used by [67]. For a population of 300, a sampling size of approximately 169 respondents is used. The conceptual model was then used to examine the responses. It is acceptable to analyze the data through structural equation modeling and create a sample size; hence, the sample size of 366 used in the study was way more than the unnecessary requirements used for hypotheses testing [68]. It must be remembered that the stated hypotheses were developed in the light of present theories but were taken in the context of E-learning.

Table 1. Participant's details

\begin{tabular}{lc}
\hline University & No. of students \\
\hline University of Fujairah (UOF) & 216 \\
The British University in Dubai (BUiD) & 150 \\
\hline
\end{tabular}

\subsection{Study instrument}

As mentioned before in the research, the hypothesis was tested through a survey instrument. The number of sources of the constructs involved in the questionnaire is shown in table 2 . The survey involves seventeen items with the goal of assessing the six constructs in the questionnaire. Some questions were also taken from the previous studies and included in this study as an attempt to make the study more logical and relatable. Though the questions which the researcher took from the past studies were changed and adjusted according to the study context.

Table 2. Construct and their sources

\begin{tabular}{lcc}
\hline Constructs & Number of items & Source \\
\hline Accessibility & 3 & {$[9],[26],[51]$} \\
Enjoyment & 3 & {$[26],[27],[51]$} \\
Subjective norm & 3 & {$[51],[69],[70]$} \\
Perceived Ease of Use & 3 & {$[23],[51],[69]$} \\
Perceived Usefulness & 3 & {$[51],[69],[71]$} \\
Intention to Use the E-Learning System & 2 & {$[9],[51]$} \\
\hline
\end{tabular}

\subsection{Instrumentation}

A tough phase of pre-testing and pilot testing of measures was started once some E-learning users and experts were chosen. The genuine measures of the research are shown in table 3 . In the questionnaire, there are three items for each construct and a five-point Likert scale was used to measure these constructs. The scale goes from "strongly disagree" to "strongly agree". The respondents were asked to choose the response they agree to while keeping in view the given statements. In addition to this, demographic information was also required by the respondents.

\subsection{Pre-test of the questionnaire}

University of Fujairah (UOF) and The British University in Dubai (BUiD), two very renowned educational institutions, took part in the study. The researcher took these universities as the target population consisting of a group of E-learning users who have good experience and knowledge about online learning system. For the pilot study, the researcher used $10 \%$ of the total sample size of the research survey i.e. 400 respondents. The sample size was chosen in light of the standard research practices. In addition to this, all the questions involved in the questionnaire were pre-tested where 40 students were used who were chosen on random basis. Moreover, as per [72], the reliability of the study was found through Cronbach's Alpha 
whose results showed that the alpha values of all variables exceed 0.7 , which has been demonstrated in Table 3. The results indicate the questionnaire used for the study is very reliable. It was ensured that all the respondents understood the final questionnaire as an attempt to further increase the overall reliability and survey quality.

Table 3. Cronbach's Alpha values for the pilot study (Cronbach's Alpha $\geq 0.70$ )

\begin{tabular}{lc}
\hline Construct & Cronbach's Alpha \\
\hline Accessibility & 0.825 \\
Enjoyment & 0.889 \\
Subjective norm & 0.766 \\
Perceived Ease of Use & 0.798 \\
Perceived Usefulness & 0.728 \\
Intention to Use the E-learning System & 0.880 \\
\hline
\end{tabular}

\subsection{Students' personal information/demographic data}

The detailed information regarding the respondents can be seen in Table 4. Nearly the same features were shared by all the participants of the study. A total of 198 females were included which makes 54\% of the total participants where 168 males were included which makes $46 \%$ of the total participants. Majority of the respondents were between the ages of $18-29$, where $65 \%$ of the respondents were between the ages of $30-39,27 \%$ were between the ages of $40-49,5 \%$ between the ages of $50-59$. The detailed demographic information of the respondents is demonstrated in Table 4.

Table 4. Summary of Students' demographic characteristic

\begin{tabular}{lcc}
\hline Variables & No. of respondents & Percent $\%$ \\
\hline Gender: & 168 & \\
Male & 198 & $46 \%$ \\
Female & & $54 \%$ \\
Age: & 238 & \\
18 to 29 years & 100 & $65 \%$ \\
30 to 39 years & 18 & $27 \%$ \\
40 to 49 years & 10 & $5 \%$ \\
50 to 59 years & & $3 \%$ \\
College: & 219 & \\
College of Business & 53 & $60 \%$ \\
College of IT & 29 & $14 \%$ \\
College of Education & 65 & $8 \%$ \\
College of Humanities & & $18 \%$ \\
Level of education: & 274 & $38 \%$ \\
Bachelor & 92 & $25 \%$ \\
Master & 0 & $0 \%$ \\
PhD & & \\
\hline
\end{tabular}

\section{FINDINGS AND DISCUSSIONS}

Smart PLS software, which was developed by [73], is used in this study for Partial Least Squares Structural Equation Modeling (PLS, SEM). It is a renowned software and is extensively used in academia [74, 75]. The software is easily accessible to academics and researchers. In addition to this, the software involves an extremely user-friendly interface and modern reporting characteristics. Due to these characteristics, the software has been gaining a lot of popularity since its introduction in 2005 [76]. The two classes of validities i.e. convergent validity and discriminate validity are usually used to assess any measurement model [77]. The measurement model describes the link between the indicators and latent construct that is being assessed.

\subsection{Data analysis}

The Reliability of indicators can be assessed easily by examining the extent to which indicators show internal consistency in a relationship with any construct. Hence, the reliability of indicators can be measured through Cronbach coefficient alpha [78] and the composite reliabilities coefficient [79]. The minimum acceptable limit of composite reliabilities is $0.70[80,81]$. The values of all the coefficients and Cronbach coefficient alpha levels are shown in Table 5. All the values were greater than 0.70 , which verifies the quality of research [82]. The data was analyzed by employing a two-stage methodology in which 
at first the measurement model is developed and then assessed independently from the complete structural equal model [83]. Due to that, every item, convergent and discriminate validity of constructs were checked for reliability as an initial step. Each item is checked for individual reliability through loadings or correlations that exist between the items and construct. The convergent validity per construct is appropriate in case of a loading greater than 0.505 [84]. Table 5 shows that there is a strong agreement between the loadings for each item and established conditions.

Factor loading, variance extracted and reliability is used as indicators by following [72] in order to guess the convergent validity's relative value. The composite reliability (CR) and reliability coefficient go above 0.7 for each construct which shows that different measurements of a construct are internally consistent with each other [72]. Cronbach's alpha values go beyond the acceptable value of 0.7 [80, 81] whereas composite reliabilities of constructs go from 0.7444 to 0.874 . This has been shown in Table 5 . Moreover, the standard of explaining a minimum of $50 \%$ of variance extracted from a collection of items triggering the latent construct is fulfilled by all average variance extracted (AVE) values which vary from 0.636 to 0.778 [84]. Therefore, it is believed that the scales through which constructs are measured have convergent validity.

It was recommended to consider two criteria i.e. Cornell-Barker criterion and the Hetero traditionalism proportion (HTMT) for achieving the measurement for discriminate validity [85]. Table 6 presents that Cornell-Barker measure verifies that the square roots of all AVEs are more important than its correlation with the remaining constructs [86]. Table 7 presents the HTMT ratio which clearly shows that each construct's value does not exceed the threshold value of 0.85 [87]. This, therefore, verifies the HTMT ratio value. The existence of discriminant validity is confirmed by these results. The data analysis indicates that reliability and validity of the measurement model were measured easily and no issues were encountered. Hence, the collected data can be used to assess the structural model.

Table 5. Convergent validity results which assure acceptable values. (Factor loading, Cronbach's Alpha, composite reliability $\geq 0.70$ \& AVE $>0.5)$

\begin{tabular}{|c|c|c|c|c|c|}
\hline Constructs & Items & Factor loading & Cronbach's Alpha & $\mathrm{CR}$ & AVE \\
\hline Intention to Use & IU1 & 0.891 & 0.803 & 0.768 & 0.651 \\
\hline \multirow{2}{*}{ the E-learning System } & IU2 & 0.728 & & & \\
\hline & IU3 & 0.887 & & & \\
\hline \multirow[t]{3}{*}{ Enjoyment } & ENJ1 & 0.918 & 0.879 & 0.781 & 0.639 \\
\hline & $\mathrm{ENJ} 2$ & 0.893 & & & \\
\hline & ENJ3 & 0.797 & & & \\
\hline \multirow[t]{3}{*}{ Accessibility } & $\mathrm{ACC} 1$ & 0.868 & 0.778 & 0.808 & 0.778 \\
\hline & $\mathrm{ACC} 2$ & 0.882 & & & \\
\hline & ACC3 & 0.867 & & & \\
\hline \multirow[t]{3}{*}{ Subjective Norm } & SUB1 & 0.700 & 0.888 & 0.778 & 0.718 \\
\hline & SUB2 & 0.778 & & & \\
\hline & SUB3 & 0.820 & & & \\
\hline \multirow[t]{3}{*}{ Perceived Ease of Use } & PEOU1 & 0.818 & 0.789 & 0.744 & 0.636 \\
\hline & PEOU2 & 0.769 & & & \\
\hline & PEOU3 & 0.753 & & & \\
\hline \multirow[t]{3}{*}{ Perceived Usefulness } & PU1 & 0.894 & 0.769 & 0.874 & 0.727 \\
\hline & PU2 & 0.711 & & & \\
\hline & PU3 & 0.709 & & & \\
\hline
\end{tabular}

Table 6. Fornell-larcker scale

\begin{tabular}{|c|c|c|c|c|c|c|}
\hline & IU & ENJ & $\mathrm{ACC}$ & SUB & PEOU & $\mathrm{PU}$ \\
\hline IU & 0.837 & & & & & \\
\hline ENJ & 0.236 & 0.769 & & & & \\
\hline $\mathrm{ACC}$ & 0.400 & 0.367 & 0.883 & & & \\
\hline SUB & 0.443 & 0.538 & 0.109 & 0.821 & & \\
\hline PEOU & 0.358 & 0.269 & 0.169 & 0.550 & 0.834 & \\
\hline PU & 0.222 & 0.399 & 0.405 & 0.220 & 0.529 & 0.747 \\
\hline
\end{tabular}

Table 7. Heterotrait-monotrait ratio (HTMT)

\begin{tabular}{ccccccc}
\hline & IU & ENJ & ACC & SUB & PEOU & PU \\
\hline IU & & & & & & \\
ENJ & 0.292 & & & & & \\
ACC & 0.636 & 0.219 & & & & \\
SUB & 0.255 & 0.339 & 0.336 & & & \\
PEOU & 0.367 & 0.344 & 0.568 & 0.692 & & \\
PU & 0.611 & 0.447 & 0.715 & 0.455 & 0.299 & \\
\hline
\end{tabular}




\subsection{Hypothesis testing and coefficient of determination}

The structural equation modeling (SEM) approach [88-96] was used to test the aforementioned nine hypotheses together. The variance described (R2 value) by each path and every hypothesized connection's path significance in the research model were assessed. The standardized path coefficients and path significances are demonstrated in Figure 2 and Table 3. Table 8 shows that the R 2 values for the intention to use the E-Learning system, perceived ease of use and perceived usefulness ranged between 0.466 and 0.537 . Therefore, these constructs appear to have Moderate predictive power [88]. Generally, the data supported eight out of nine hypotheses. According to previous studies, all TAMs' constructs were verified in the model (PEOU, PU, and BI). Based on the data analysis hypotheses H1a, H1b, H2a, H2b, H3a, H4, H5, and H6 were supported by the empirical data, while $\mathrm{H} 3 \mathrm{~b}$ was rejected. The results in table 9 showed that Perceived Ease of Use (PEOU) significantly influenced Enjoyment (ENJ) $(\beta=0.380, \mathrm{P}<0.001)$, Accessibility (ACC) $(\beta=0.365$, $\mathrm{P}<0.05)$, and Subjective norm (SUB) $(\beta=0.280, \mathrm{P}<0.05)$ supporting hypothesis H1a, H2a, and H3a respectively. Perceived Usefulness (PU) was determined to be significant in affecting Enjoyment (ENJ) $(\beta=0.655, \mathrm{P}<0.05)$, Accessibility $(\mathrm{ACC})(\beta=0.473, \mathrm{P}<0.001)$, and Perceived Ease of Use (PEOU) $(\beta=0.275$, $\mathrm{P}<0.001)$ supporting hypotheses $\mathrm{H} 1 \mathrm{~b}, \mathrm{H} 2 \mathrm{~b}$, and $\mathrm{H} 4$. Intention to Use the E-Learning System (IU) has significant effects on Perceived Ease of Use (PEOU) $(\beta=0.369, \mathrm{P}<0.001)$ and Perceived Usefulness (PU) $(\beta=0.515, \mathrm{P}<0.001)$ respectively; hence, H5 and H6 are supported. Finally, Subjective norm (SUB) has insignificant effects on Perceived Usefulness (PU) $(\beta=0.190, \mathrm{P}<0.001)$ then, $\mathrm{H} 3 \mathrm{~b}$ is not supported.

Table $8 . \mathrm{R} 2$ of the endogenous latent variables

\begin{tabular}{lcc}
\hline Constructs & R2 & Results \\
\hline Intention to Use the E-Learning System & 0.466 & Moderate \\
Perceived Ease of Use & 0.537 & Moderate \\
Perceived Usefulness & 0.526 & Moderate \\
\hline
\end{tabular}

Table 9. Summary of hypotheses tests at $\mathrm{p}^{* *}=<0.01, \mathrm{p}^{*}<0.05$ Significant at $\mathrm{p}^{* *}=<0.01, \mathrm{p}^{*}<0.05$

\begin{tabular}{|c|c|c|c|c|c|c|}
\hline $\mathrm{H}$ & Relationship & Path & t-value & p-value & Direction & Decision \\
\hline H1a & Enjoyment -> Perceived Ease of Use & 0.380 & 11.288 & 0.001 & Positive & Supported** \\
\hline $\mathrm{H} 1 \mathrm{~b}$ & Enjoyment -> Perceived Usefulness & 0.655 & 5.219 & 0.021 & Positive & Supported* \\
\hline $\mathrm{H} 2 \mathrm{a}$ & Accessibility $\rightarrow$ Perceived Ease of Use & 0.365 & 4.469 & 0.011 & Positive & Supported* \\
\hline $\mathrm{H} 2 \mathrm{~b}$ & Accessibility -> Perceived Usefulness & 0.473 & 8.179 & 0.002 & Positive & Supported $* *$ \\
\hline $\mathrm{H} 3 \mathrm{a}$ & Subjective norm -> Perceived Ease of Use & 0.280 & 3.866 & 0.027 & Positive & Supported $^{*}$ \\
\hline $\mathrm{H} 3 \mathrm{~b}$ & Subjective norm -> Perceived Usefulness & 0.190 & 1.109 & 0.246 & Positive & Not supported \\
\hline $\mathrm{H} 4$ & Perceived Ease of Use -> Perceived Usefulness & 0.275 & 16.891 & 0.000 & Positive & Supported $* *$ \\
\hline H5 & $\begin{array}{l}\text { Perceived Ease of Use -> Intention to Use } \\
\text { the E-Learning System }\end{array}$ & 0.369 & 20.590 & 0.000 & Positive & Supported $* *$ \\
\hline H6 & $\begin{array}{l}\text { Perceived Usefulness -> Intention to Use } \\
\text { the E-Learning System }\end{array}$ & 0.515 & 18.137 & 0.000 & Positive & Supported $* *$ \\
\hline
\end{tabular}

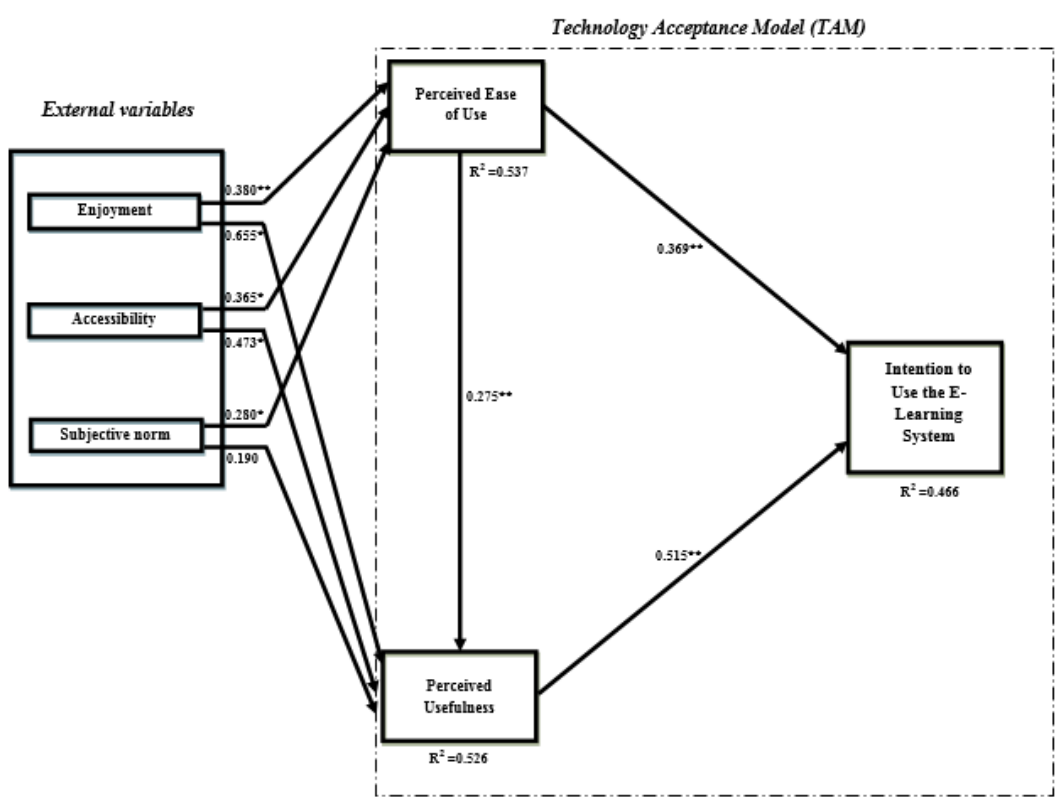

Figure 2. Hypotheses testing results (significant at $\mathrm{p}^{* *}<=0.01, \mathrm{p}^{*}<0.05$ ) 


\section{CONCLUSION AND FUTURE WORKS}

The study aims to extract factors through which the views concerning E-learning are affected. The study is conducted on the students of UAE. In order to present the proposed research model relevance and hypothesis used for analyzing the behavioral intention to accept E-learning system, the outcomes of data analysis are paid considerable attention. Structure equation modeling (PLS-SEM) was used to analyze the research hypotheses. Figure 2 shows the structural model which is evaluated by examining the structural paths, variance explained (R-squared value) and t-statistics. Table 9 shows the results of data analysis. PLS technique has been used to test the aforementioned nine hypotheses. Upon the path significance of every hypothesized association which is included in the research model and the variance explained (R2) by each path, an assessment was done. Out of all nine hypotheses, eight hypotheses were supported. The hypotheses which were achieved through TAM model (H1a, H1b, H2a, H2b, H3a, H4, H5, and, H6) have been confirmed. The results show that factors like perceived ease of use, subjective norm, accessibility, enjoyment, and perceived usefulness can improve the behavioral intention to embrace E-learning system. The literature review supports these results. Accordingly, it can be assumed that E-learning is quite important when it comes to proficiency and high confidence levels while using online learning platforms.

The study has some limitations which have been mentioned in this part. The research was conducted using only two universities in UAE which is the biggest limitation since the selection was quite limited to study how E-learning system acceptance is affected by different factors. The study could have become more appropriate had the researcher included more universities in UAE in the research. By conducting more research and developing a more genuine understanding of the E-learning system, the factors which affect the actual E-learning system can be understood in a much better way. Another limitation was taking only 366 students as the participants of the study. A survey questionnaire was used to collect the data. In order to achieve more accurate results, a better instrument and sampling method could be used and more educational institutions from other areas such as the Arab Gulf region in which countries like KSA, Kuwait, and Bahrain could be included. In addition to this, in future research, more students will be asked to participate in the study. For better results, focus group, as well as interviews, will be performed. We will also encourage the Arab universities that have participated in the study to incorporate E-learning systems.

\section{ACKNOWLEDGEMENTS}

I would like to express my special thanks of gratitude to my parents and my wife for encouraging me to complete my research; they have done a lot to support me during the progress of this research.

\section{REFERENCES}

[1] K. M. Alomari, A. Q. AlHamad, S. Salloum and S. A. Salloum, "Prediction of the digital game rating systems based on the ESRB," Opcion, vol. 35, no. 19, pp. 1368-1393, 2019.

[2] H.-R. Chen and H.-F. Tseng, "Factors that influence acceptance of web-based e-learning systems for the in-service education of junior high school teachers in Taiwan," Eval. Program Plann., vol. 35, no. 3, pp. 398-406, 2012.

[3] N. F. Al-Mushasha and A. B. Nassuora, "Factors determining e-learning service quality in Jordanian higher education environment," J. Appl. Sci., vol. 12, no. 14, pp. 1474-1480, 2012.

[4] B. H. Khan, "Managing e-learning: Design, delivery, implementation, and evaluation," IGI Global, 2005.

[5] N. F. A. Al-Mushasha, "Determinants of e-learning acceptance in higher education environment based on extended technology acceptance model," 2013 Fourth International Conference on e-Learning "Best Practices in Management, Design and Development of e-Courses: Standards of Excellence and Creativity, Manama, pp. 261-266, 2013

[6] B. Žvanut, P. Pucer, S. Ličen, I. Trobec, N. Plazar, and D. Vavpotič, "The effect of voluntariness on the acceptance of e-learning by nursing students," Nurse Educ. Today, vol. 31, no. 4, pp. 350-355, 2011.

[7] Z. Liu and Z. Wei, "Research on Chinese College Students' using behavior towards E-learning services based on improved TAM model," 2nd International Conference on Social Science, Public Health and Education (SSPHE 2018), 2019.

[8] A. Q. AlHamad, M. Salameh, and L. Al Makhareez, "Identifying students' trends toward personalizing learning management system (LMS) at Zarqa University (Extended)," J. Inf. Technol. Econ. Dev., vol. 5, no. 1, pp. 36-46, 2014.

[9] S. Y. Park, "An analysis of the technology acceptance model in understanding university students' behavioral intention to use e-learning," J. Educ. Technol. Soc., vol. 12, no. 3, pp. 150-162, 2009.

[10] A. Q. Alhamad, A. M. Elshamy, W. Maqableh, and A. Qasim, "Implementation for personal document processing system," International Conference on Computer and Applications (ICCA), Doha, pp. 147-150, 2017.

[11] J. C. Roca, C.-M. Chiu, and F. J. Martínez, "Understanding e-learning continuance intention: An extension of the technology acceptance model," Int. J. Hum. Comput. Stud., vol. 64, no. 8, pp. 683-696, 2006.

[12] T. Teo, "Development and validation of the E-learning acceptance measure (ElAM)," Internet High. Educ., vol. 13, no. 3, pp. 148-152, 2010. 
[13] A. Q. AlHamad and K. I. Al Qawasmi, "Building an Ethical Framework for E-learning Management System at a University Level," J. Eng. Econ. Dev., vol. 1, no. 1, p. 11, 2014.

[14] F.-C. Lo, J.-C. Hong, M.-X. Lin, and C.-Y. Hsu, "Extending the technology acceptance model to investigate impact of embodied games on learning of Xiao-zhuan ( ( 登)," Procedia-Social Behav. Sci., vol. 64, pp. 545-554, 2012.

[15] F. D. Davis, R. P. Bagozzi, and P. R. Warshaw, "User acceptance of computer technology: A comparison of two theoretical models," Manage. Sci., vol. 35, no. 8, pp. 982-1003, 1989.

[16] M. Fishbein and I. Ajzen, "Belief, attitude, intention and behavior: An introduction to theory and research," Addison-Wesley, 1975.

[17] V. Venkatesh, "Determinants of perceived ease of use: Integrating control, intrinsic motivation, and emotion into the technology acceptance model," Inf. Syst. Res., vol. 11, no. 4, pp. 342-365, 2000.

[18] S. Alharbi and S. Drew, "Using the technology acceptance model in understanding academics' behavioural intention to use learning management systems," Int. J. Adv. Comput. Sci. Appl., vol. 5, no. 1, pp. 143-155, 2014.

[19] M. A. Al-hawari and S. Mouakket, "The influence of technology acceptance model (tam) factors on students' e-satisfaction and e-retention within the context of UAE e-learning," Educ. Bus. Soc. Contemp. Middle East. Issues, vol. 3, no. 4, pp. 299-314, 2010.

[20] A. Alia, "An investigation of the application of the technology acceptance model (TAM) to evaluate instructors' perspectives on E-Learning at Kuwait University," PhD Thesis, Dublin City University, 2017.

[21] J. H. Al-Ammary, A. K. Al-Sherooqi, and H. K. Al-Sherooqi, "The acceptance of social networking as a learning tools at University of Bahrain," Int. J. Inf. Educ. Technol., vol. 4, no. 2, pp. 208-214, 2014.

[22] S. S. Al-Gahtani, "Empirical investigation of e-learning acceptance and assimilation: A structural equation model," Appl. Comput. Informatics, vol. 12, no. 1, pp. 27-50, 2016.

[23] C.-T. Chang, J. Hajiyev, and C.-R. Su, "Examining the students' behavioral intention to use e-learning in Azerbaijan? The general extended technology acceptance model for E-learning approach," Comput. Educ., vol. 111, pp. 128-143, 2017.

[24] A. M. Elkaseh, K. W. Wong, and C. C. Fung, "The acceptance of e-learning as a tool for teaching and learning in Libyan higher education," IPASJ Int. J. Inf. Technol., vol. 3, no. 4, pp. 1-11, 2015.

[25] F. Kanwal and M. Rehman, "Factors affecting E-Learning adoption in developing countries-empirical evidence from Pakistan's Higher Education Sector,” IEEE Access, vol. 5, pp. 10968-10978, 2017.

[26] M. R. Martínez-Torres, S. L. Toral Marín, F. B. Garcia, S. G. Vazquez, M. A. Oliva, and T. Torres, "A technological acceptance of e-learning tools used in practical and laboratory teaching, according to the European higher education area," Behav. Inf. Technol., vol. 27, no. 6, pp. 495-505, 2008.

[27] Y.-C. Lin, Y.-C. Chen, and R. C. Yeh, "Understanding college students' continuing intentions to use multimedia e-learning systems," World Trans. Eng. Technol. Educ., vol. 8, no. 4, pp. 488-493, 2010.

[28] P. E. Ramírez-Correa, J. Arenas-Gaitán, and F. J. Rondán-Cataluña, "Gender and acceptance of E-learning: A multi-group analysis based on a structural equation model among college students in Chile and Spain," PLoS One, vol. 10, no. 10, pp. 1-17, 2015.

[29] C. Yi-Cheng, C. Chun-Yu, L. Yi-Chen, and Y. Ron-Chen, "Predicting college student' use of e-learning systems: An attempt to extend technology acceptance model," PACIS Proc., pp. 172-183, 2007.

[30] A. Y. Alsabawy, A. Cater-Steel, and J. Soar, "Determinants of perceived usefulness of e-learning systems," Comput. Human Behav., vol. 64, pp. 843-858, 2016.

[31] S. H. Alshammari, M. B. Ali, and M. S. Rosli, "The influences of technical support, self efficacy and instructional design on the usage and acceptance of LMS: A comprehensive review.," Turkish Online J. Educ. Technol., vol. 15, no. 2, pp. 116-125, 2016.

[32] R. Arteaga Sánchez, A. Duarte Hueros, and M. García Ordaz, "E-learning and the University of Huelva: A study of WebCT and the technological acceptance model," Campus-Wide Inf. Syst., vol. 30, no. 2, pp. 135-160, 2013.

[33] J. Attis, "An investigation of the variables that predict teacher e-learning acceptance," Dissertation, Liberty University, 2014.

[34] A. Al-Aulamie, "Enhanced technology acceptance model to explain and predict learners' behavioural intentions in learning management systems," PhD Theses, University of Bedfordshire, 2013.

[35] M. A. Almaiah, M. A. Jalil, and M. Man, "Extending the TAM to examine the effects of quality features on mobile learning acceptance," J. Comput. Educ., vol. 3, no. 4, pp. 453-485, 2016.

[36] S. Y. Park, M. Nam, and S. Cha, "University students' behavioral intention to use mobile learning: Evaluating the technology acceptance model," Br. J. Educ. Technol., vol. 43, no. 4, pp. 592-605, 2012.

[37] A. Revythi and N. Tselios, "Extension of technology acceptance model by using system usability scale to assess behavioral intention to use e-learning," Education and Information technologies, pp. 1-15, 2017.

[38] F. A. Bachtiar, A. Rachmadi, and F. Pradana, "Acceptance in the deployment of blended learning as a learning resource in information technology and computer science program, Brawijaya University," Asia-Pacific Conference on Computer Aided System Engineering (APCASE), pp. 131-135, 2014.

[39] S. Baleghi-Zadeh, A. F. M. Ayub, R. Mahmud, and S. M. Daud, "Behaviour intention to use the learning management: Integrating technology acceptance model with task-technology fit," Middle-East J. Sci. Res., vol. 19, no. 1 , pp. 76-84, 2014.

[40] W. Wongvilaisakul and S. Lekcharoen, "The acceptance of e-Learning using SEM approach: A case of IT Literacy development for PIM students," 12th International Conference on Electrical Engineering/Electronics, Computer, Telecommunications and Information Technology (ECTI-CON), pp. 1-6, 2015. 
[41] E. M. Van Raaij and J. J. L. Schepers, "The acceptance and use of a virtual learning environment in China," Comput. Educ., vol. 50, no. 3, pp. 838-852, 2008.

[42] K. A. Al-Busaidi, "An empirical investigation linking learners' adoption of blended learning to their intention of full e-learning," Behav. Inf. Technol., vol. 32, no. 11, pp. 1168-1176, 2013.

[43] A. R. Alenezi, A. M. Abdul Karim, and A. Veloo, "Institutional support and e-learning acceptance: An extension of the technology acceptance model," Int. J. Instr. Technol. Distance Learn., vol. 8, no. 2, pp. 3-16, 2011.

[44] M. Abbad, D. Morris, A. E. Al-Ayyoub, and J. Abbad, "Students' decisions to use an eLearning system: A structural equation modelling analysis.," iJET, vol. 4, no. 4, pp. 4-13, 2009.

[45] T. Teo and M. Zhou, "The influence of teachers' conceptions of teaching and learning on their technology acceptance," Interact. Learn. Environ., vol. 25, no. 4, pp. 513-527, 2017.

[46] A. H. K. Yuen and W. W. K. Ma, "Exploring teacher acceptance of e-learning technology," Asia-Pacific J. Teach. Educ., vol. 36, no. 3, pp. 229-243, 2008.

[47] Y.-H. Lee, Y.-C. Hsieh, and C.-Y. Ma, "A model of organizational employees' e-learning systems acceptance," Knowledge-based Syst., vol. 24, no. 3, pp. 355-366, 2011.

[48] H. Motaghian, A. Hassanzadeh, and D. K. Moghadam, "Factors affecting university instructors' adoption of web-based learning systems: Case study of Iran," Comput. Educ., vol. 61, pp. 158-167, 2013.

[49] F. D. Davis, "Perceived usefulness, perceived ease of use, and user acceptance of information technology," MIS Quarterly, vol. 13, no. 3, pp. 319-340, 1989.

[50] V. Venkatesh and H. Bala, "Technology acceptance model 3 and a research agenda on interventions," Decis. Sci., vol. 39, no. 2, pp. 273-315, 2008.

[51] S. A. S. Salloum and K. Shaalan, "Investigating students' acceptance of E-learning system in higher educational environments in the UAE: Applying the extended technology acceptance model (TAM)," Dissertation, The British University in Dubai, 2018.

[52] Y.-L. Theng et al., "An empirical study of students' perceptions on e-learning systems," Proceedings of the 2nd International Convention on Rehabilitation Engineering \& Assistive Technology, pp. 245-249, 2008.

[53] D. U. Vidanagama, "Acceptance of E-learning among undergraduates of computing degrees in Sri Lanka," Int. J. Mod. Educ. Comput. Sci., vol. 8, no. 4, p. 25, 2016.

[54] J. Zhao and W. Tan, "E-learning systems adoption across cultures: a comparison study," International Conference on E-Product E-Service and E-Entertainment, pp. 1-4, 2010.

[55] P. Mbengo, "E-learning adoption by lecturers in selected Zimbabwe State Universities: An application of technology acceptance model," J. Bus. Adm. Educ., vol. 6, no. 1, pp. 15-33, 2014.

[56] J. A. Smith and S. A. Sivo, "Predicting continued use of online teacher professional development and the influence of social presence and sociability," Br. J. Educ. Technol., vol. 43, no. 6, pp. 871-882, 2012

[57] G. W.-H. Tan, K.-B. Ooi, J.-J. Sim, and K. Phusavat, "Determinants of mobile learning adoption: An empirical analysis," J. Comput. Inf. Syst., vol. 52, no. 3, pp. 82-91, 2012.

[58] A. Tarhini, K. Hone, X. Liu, and T. Tarhini, "Examining the moderating effect of individual-level cultural values on users' acceptance of E-learning in developing countries: A structural equation modeling of an extended technology acceptance model," Interact. Learn. Environ., vol. 25, no. 3, pp. 306-328, 2017.

[59] S. A. Salloum and K. Shaalan, "Investigating students' acceptance of e-learning system in higher educational environments in the UAE: Applying the extended technology acceptance model (TAM)," Dissertation, The British University in Dubai, 2018.

[60] S. A. Saaid and J. A. Rashid, "Interoperability of e-publishing: Knowledge and perception of iLearn system among students," in International Conference on Education and e-Learning (EeL). Proceedings, pp. 184, 2012.

[61] N. Sandjojo and T. Wahyuningrum, "Measuring e-learning systems success: Implementing D \& M is success model," 4th International Conference on Interactive Digital Media (ICIDM), pp. 1-6, 2015.

[62] G. U. D. Shah, M. N. Bhatti, M. Iftikhar, M. I. Qureshi, and K. Zaman, "Implementation of technology acceptance model in e-learning environment in rural and urban areas of Pakistan," World Appl. Sci. J., vol. 27, no. 11, pp. 1495-1507, 2013.

[63] J. J. Siang and H. B. Santoso, "Students' perspective of learning management system: An empirical evidence of technology acceptance model in emerging countries," Journal of Arts, Science, \& Commerce, vol. 6, no. 2, pp. 1-14, 2015.

[64] F. Calisir, C. Altin Gumussoy, A. E. Bayraktaroglu, and D. Karaali, "Predicting the intention to use a web-based learning system: Perceived content quality, anxiety, perceived system quality, image, and the technology acceptance model," Hum. Factors Ergon. Manuf. Serv. Ind., vol. 24, no. 5, pp. 515-531, 2014.

[65] C.-C. Chang, K.-H. Tseng, C. Liang, and C.-F. Yan, "The influence of perceived convenience and curiosity on continuance intention in mobile English learning for high school students using PDAs," Technol. Pedagog. Educ., vol. 22, no. 3, pp. 373-386, 2013.

[66] C.-Y. Chiang, K. Boakye, and X. Tang, "The investigation of E-learning system design quality on usage intention," J. Comput. Inf. Syst., vol. 59, no. 3, pp. 1-10, 2017.

[67] R. V Krejcie and D. W. Morgan, "Determining sample size for research activities," Educ. Psychol. Meas., vol. 30, no. 3, pp. 607-610, 1970

[68] C. L. Chuan and J. Penyelidikan, "Sample size estimation using Krejcie and Morgan and Cohen statistical power analysis: A comparison," J. Penyelid. IPBL, vol. 7, pp. 78-86, 2006.

[69] M.-C. Lee, "Explaining and predicting users' continuance intention toward e-learning: An extension of the expectation-confirmation model," Comput. Educ., vol. 54, no. 2, pp. 506-516, 2010. 
[70] T.-H. Chu and Y.-Y. Chen, "With good we become good: Understanding e-learning adoption by theory of planned behavior and group influences," Comput. Educ., vol. 92, pp. 37-52, 2016.

[71] T. Teo, "Examining the influence of subjective norm and facilitating conditions on the intention to use technology among pre-service teachers: A structural equation modeling of an extended technology acceptance model," Asia Pacific Educ. Rev., vol. 11, no. 2, pp. 253-262, 2010.

[72] J. F. Hair, W. C. Black, B. J. Babin, R. E. Anderson, and R. L. Tatham, "Multivariate data analysis," Prentice Hall, 1998.

[73] C. M. Ringle, S. Wende, and A. Will, "SmartPLS 2.0 (Beta). Hamburg," Available at: http://www. smartpls.de, 2005.

[74] S. A. Salloum and M. Al-Emran, "Factors affecting the adoption of e-payment systems by university students: Extending the TAM with trust," Int. J. Electron. Bus., vol. 14, no. 4, pp. 371-390, 2018.

[75] M. Alshurideh, S. A. Salloum, B. Al Kurdi, and M. Al-Emran, "Factors affecting the social networks acceptance: An empirical study using PLS-SEM approach," 8th International Conference on Software and Computer Applications, pp. 414-418, 2019.

[76] K. K.-K. Wong, "Partial least squares structural equation modeling (PLS-SEM) techniques using SmartPLS," Mark. Bull., vol. 24, no. 1, pp. 1-32, 2013.

[77] W. W. Chin, "The partial least squares approach to structural equation modeling," Mod. Methods Bus. Res., vol. 295, no. 2, pp. 295-336, 1998.

[78] L. J. Cronbach and L. Furby, "How we should measure" change: Or should we?," Psychol. Bull., vol. 74, no. 1, pp. 68-80, 1970.

[79] C. E. Werts, R. L. Linn, and K. G. Jöreskog, "Intraclass reliability estimates: Testing structural assumptions," Educ. Psychol. Meas., vol. 34, no. 1, pp. 25-33, 1974.

[80] D. Gefen, D. Straub, and M.-C. Boudreau, "Structural equation modeling and regression: Guidelines for research practice," Commun. Assoc. Inf. Syst., vol. 4, no. 7, pp. 1-77, 2000.

[81] J. C. Nunnally and I. H. Bernstein, "Psychometric theory," McGraw-Hill, 1978.

[82] G. A. Churchill Jr, "A paradigm for developing better measures of marketing constructs," J. Mark. Res., vol. 16, no. 1, pp. 64-73, 1979.

[83] J. C. Anderson and D. W. Gerbing, "Structural equation modeling in practice: A review and recommended two-step approach," Psychol. Bull., vol. 103, no. 3, pp. 411-423, 1988.

[84] R. F. Falk and N. B. Miller, “A primer for soft modeling," University of Akron Press, 1992.

[85] J. Hair, C. L. Hollingsworth, A. B. Randolph, and A. Y. L. Chong, "An updated and expanded assessment of PLS-SEM in information systems research,” Ind. Manag. Data Syst., vol. 117, no. 3, pp. 442-458, 2017.

[86] C. Fornell and D. F. Larcker, "Evaluating structural equation models with unobservable variables and measurement error," J. Mark. Res., vol. 18, no. 1, pp. 39-50, 1981.

[87] J. Henseler, C. M. Ringle, and M. Sarstedt, "A new criterion for assessing discriminant validity in variance-based structural equation modeling," J. Acad. Mark. Sci., vol. 43, no. 1, pp. 115-135, 2015.

[88] F. D. Davis, R. P. Bagozzi, and P. R. Warshaw, "Extrinsic and intrinsic motivation to use computers in the workplace," J. Appl. Soc. Psychol., vol. 22, no. 14, pp. 1111-1132, 1992.

[89] M. Alshurideh, B. Al Kurdi, and S. A. Salloum, "Examining the main mobile learning system drivers' effects: A mix empirical examination of both the expectation-confirmation model (ECM) and the technology acceptance model (TAM)," International Conference on Advanced Intelligent Systems and Informatics, pp. 406-417, 2019.

[90] S. F. S. Alhashmi, S. A. Salloum, and S. Abdallah, "Critical success factors for implementing artificial intelligence (AI) projects in Dubai Government United Arab Emirates (UAE) health sector: Applying the extended technology acceptance model (TAM)," in International Conference on Advanced Intelligent Systems and Informatics, pp. 393-405, 2019.

[91] S. A. Salloum, M. Al-Emran, M. Habes, M. Alghizzawi, M. A. Ghani, and K. Shaalan, "Understanding the impact of social media practices on e-learning systems acceptance," International Conference on Advanced Intelligent Systems and Informatics, pp. 360-369, 2019.

[92] M. T. Alshurideh, S. A. Salloum, B. Al Kurdi, A. A. Monem, and K. Shaalan, "Understanding the quality determinants that influence the intention to use the mobile learning platforms: A practical study," Int. J. Interact. Mob. Technol., vol. 13, no. 11, pp. 157-183, 2019.

[93] R. S. Al-Maroof, S. A. Salloum, A. Q. M. AlHamadand, and K. Shaalan, "a unified model for the use and acceptance of stickers in social media messaging," International Conference on Advanced Intelligent Systems and Informatics, pp. 370-381, 2019.

[94] . A. Salloum, A. Q. M. Alhamad, M. Al-Emran, A. A. Monem, and K. Shaalan, “Exploring students' acceptance of e-learning through the development of a comprehensive technology acceptance model," IEEE Access, vol. 7, pp. 128445-128462, 2019.

[95] S. A. Salloum and K. Shaalan, "Adoption of e-book for university students," International Conference on Advanced Intelligent Systems and Informatics, pp. 481-494, 2018.

[96] S. A. Salloum and K. Shaalan, "Factors affecting students' acceptance of e-learning system in higher education using UTAUT and structural equation modeling approaches," International Conference on Advanced Intelligent Systems and Informatics, pp. 469-480, 2018. 


\section{BIOGRAPHY OF AUTHOR}

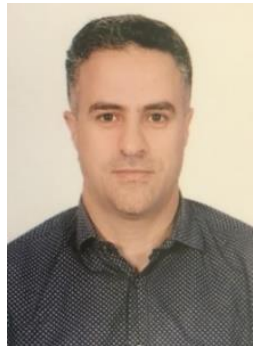

Ahmad Qasim Mohammad AlHamad received his BSc in Computer Engineering from Jordan University of Science and Technology, Irbid, Jordan in 2000; also he receives his M.Sc. degree from Queen Margaret University, Edinburgh, United kingdom in 2002, and his Ph.D. degree in information systems from Coventry University, Coventry, United Kingdom in 2011. He has 19 years of teaching experience, including being the Dean of IT College, Fujairah University for three years. He is currently an Assistant Professor with Abu Dhabi University, United Arab Emirates. His research interests include e-commerce, e-learning, Ethics in e-learning environment, e-health, e-library systems, and mobile commerce. MIS Department, Abu Dhabi University, Abu Dhabi, United Arab Emirates. 